


\title{
Pharmacological and Phytochemical Evaluation of Clitoria ternata flower and Tribulus terristris seed
}

\author{
S. Naga Subrahmanyam ${ }^{*}$, Tagoore Vijaya Lakshmi' ${ }^{1}$, M.Venkata Padma ${ }^{1}$, G.V. Pavan \\ Kumar', G.V. Naga Raju' ${ }^{1}$ \\ 1. Koringa College of Pharmacy, Koringa- 533461, Kakinda, A.P, India
}

\begin{abstract}
To evaluate the anti-inflammatory and anti-diabetic potential of extracts Clitoria ternate flower (CTF) AND Tribulus terristris seed (TTS) by in-vivo pharmacological models using rats. Ternate flower (CTF) AND Tribulus terristris seed (TTS). Extraction by cold maceration techniques using hydro-alcoholic solvent. Evaluation of chemical constituents by various chemical tests. Acute toxicity studies as per OECD guidelines and calculation of ED 50 Anti-inflammatory activity by Carragenan induced rat paw models. Anti-diabetic activity by Alloxon induced diabetes in rats. Statistical analysis by Students t Test. Extraction by Cold Maceration method. Estimation of Phytochemicals by various chemical tests.(3) Acute Toxicity studies by OECD guidelines and dose selected were $200 \mathrm{mg}$ and $400 \mathrm{mg} / \mathrm{kg}(4)$ Phytoconstituents are mostly presents in the Clitoria terneta flower and photosterols and flavonoids are not present in the Tribulus tertaris seed which are highly present in Clitoria terneta flower.Anti-inflammatory Activity of Clitoria ternata flower and Tribulus terristris seed highly seen in group III and V of CTF AND TFS. Least amount present in group II of 39\% in CTF and $45 \%$ of group IV in TTS..Anti-diabetic Activity of Clitoria ternata flower and Tribulus terristris seed values are Mean \pm SEM of Six Animals. Statistical Significance: $a=p<0.001$ and $b=p<0.05$ as compared to control From the acute toxicity studies the ED 50 of the extract were fixes as 200 and $400 \mathrm{mg} / \mathrm{kg}$. The anti-inflammatory and anti-diabetic activity of both CTF \& TTS were calculated by in-vivo methods using rat models. The $400 \mathrm{mg} / \mathrm{kg}$ of both Clitoria ternata flower (CTF) and Tribulus terristris seed (TTS) extracts showed potential anti-inflammatory and antidiabetic activity. Further studies are required for structural elucidation of the active component(s) involved in the anti-hyperglycaemic and anti-inflammatory activity of Tribulus terrestris L. and Clitoria ternate
\end{abstract}

*Corresponding Author Email: subrahmanyamsatupati@gmail.com

Received 01 September 2018, Accepted 08 September 2018

Please cite this article as: Subrahmanyam SN et al., Pharmacological and Phytochemical Evaluation of Clitoria ternata flower and Tribulus terristris seed. American Journal of Pharmacy \& Health Research 2018. 


\section{INTRODUCTION}

An ancient Indian Sanskrit literature that described the diabetes mellitus as 'madhumeha' which deals the health care systems and duly acknowledged in modern medical texts. Current studies were estimated, that diabetes mellitus is most popular and commonly appearing disorder in human population all over the world. (1)

Inflammation is the body's attempt at self-protection to remove harmful stimuli and begin the healing process. Inflammation is part of the body's immune response. Infections, wounds, and any damage to tissue would not be able to heal without an inflammatory response(2)

Aim

To evaluate the anti-inflammatory and anti-diabetic potential of extracts Clitoria ternate flower (CTF) AND Tribulus terristris seed (TTS) by in-vivo pharmacological models using rats.

\section{Objectives}

1. Collection of powders of Clitoria ternate flower (CTF) AND Tribulus terristris seed (TTS).

2. Extraction by cold maceration techniques using hydro-alcoholic solvent.

3. Evaluation of chemical constituents by various chemical tests.

4. Acute toxicity studies as per OECD guidelines and calculation of ED 50

5. -inflammatory activity by Carragenan induced rat paw models.

6. Anti-diabetic activity by Alloxon induced diabetes in rats.

7. Statistical analysis by Students t Test.

\section{MATERIAL AND METHOD}

\section{Extraction of the powdered plant material}

All the two plants powders were procured from ayuervedic shop. The powdered plant materials were then passed through a sieve No 22 and stored in air tight container for further use. Extraction was carried out using ethanol by a simple maceration technique. Seven hundred and fifty milliliter $(750 \mathrm{ml})$ of ethanol was added to $75 \mathrm{~g}$ of powder and kept on mechanical shaker for $4 \mathrm{~h}$ and filtered through Whatman No.1 filter paper. The filtrate was evaporated under reduced temperature and pressure to constant weight. The percentage yield of ethanolic extract was calculated for each plant.

\section{Animals}

Wistar albino rats of either sex (150-200 g) were used for the ex vivo study. They were housed in standard polypropylene cages and kept under controlled room temperature $\left(24 \pm 20^{\circ} \mathrm{C}\right.$, relative 
humidity $45-55 \%$ ) in a $12 \mathrm{~h}$ light-dark cycle. The rats were given a standard laboratory diet and water ad libitum

\section{Phytochemical screening}

Preliminary phytochemical screening of Clitoria ternata flower \& Tribulus terristris seed extracts were done to test the presence of the active chemical constituents such as alkaloids, flavonoids, tannins, phenolic compounds, saponins, fixed oils and fats (Khandelwal, 2008)

\section{Acute toxic studies}

Acute toxic studies were performed for both CTF and TTS extracts at a dose of $2000 \mathrm{mg} / \mathrm{kg}$ body weight in 2 groups of 6 rats respectively. The CNS activity of both group of rats were observed for its behavioral change. No death is reported for this selected dose and 1/10th of the dose selected for the anti urolithiastic activity (200mg and 400mg).

\section{Anti inflammatory activity}

Swiss albino rats were divided into five groups of six animals each. The test groups received orally $200 \& 400 \mathrm{mg} / \mathrm{kg}$ of sample. The reference group received diclofenac sodium $(10 \mathrm{mg} / \mathrm{kg}$, p.o) while the control group received vehicle (1\% tween 80). After 1h, $0.1 \mathrm{~mL}, 1 \% \mathrm{w} / \mathrm{v}$ carrageenan suspension in normal saline was injected into the subplanatar tissue of the right hind paw. The paw volume was measured at 30 min. 1, 2, 3 and $4 \mathrm{~h}$ after carageenan injection using a micrometer screw gauge. The percentage inhibition of the inflammation was calculated from the formula: \% inhibition $=(\mathrm{Vc}-\mathrm{Vt} / \mathrm{Vc}) \times 100$

Whereas Vc was the average inflammation (hind paw edema) of the control group of mice at a given time, $\mathrm{Vt}$ was the average inflammation of the drug treated (i,e sample or reference diclofenac sodium) mice at the same time.

\section{Antidiabetic activity}

Antidiabetic screening For experiment overnight fasted Wistar rats was induced by a single intraperitoneal administration of Alloxan monohydrate $(150 \mathrm{mg} / \mathrm{kg} . \mathrm{b} . \mathrm{wt})$ in $0.1 \mathrm{M}$ citrate buffer, $\mathrm{pH}$ 4.5. Those animals with fasting blood glucose level more than $300 \mathrm{mg} / \mathrm{dl}$ after alloxon administration were selected for the study and they were divided into four groups of six animals each.

Group I served as diabetic control and received 0.3\% CMC, Group II served as positive control and received glibenclamide (10 mg/kg.b.wt), Groups III and IV received the ethanolic extract of Clitoria ternate flower (200 mg/ kg.b.wt and $400 \mathrm{mg} / \mathrm{kg} . b . w t$ respectively). Groups V and VI received the ethanolic extract of Tribulus terristris sedd $(200 \mathrm{mg} / \mathrm{kg} . \mathrm{b} . \mathrm{wt}$ and $400 \mathrm{mg} / \mathrm{kg} . \mathrm{b} . \mathrm{wt}$ respectively). 


\section{Stastiscal analysis}

Statiscal analysis was carried out using one way analysis of variance (ANOVA) followed by Dunnet's multiple comparison test. P values $<0.05$ were considered significant.

\section{RESULTS AND DISCUSSION}

Table-1 Phytoconstituents of Clitoria terneta flower \& Tribulus teristaris seed Extracts

Note:

\begin{tabular}{llll}
\hline S.NO & Phytoconstituents & Clitoria terneta flower & Tribulus tertaris seed \\
\hline 1 & Saponin & ++ & ++ \\
2 & Tanins & ++ & ++ \\
3 & Alkaloids & ++ & ++ \\
4 & Glycosides & ++ & ++ \\
5 & Phtosterols & ++ & - \\
6 & Carbohdtrates & + & + \\
7. & Flavanoids & ++ & - \\
8. & Terpenoids & ++ & + \\
\hline
\end{tabular}

++ - Presence of Chemical constituents, - Absence of Chemical constituents.

Table-2 Results of In vivo anti inflammatory activity of Clitoria ternate flower (CTF) \& Tribulus terristris seed (TTS)

\begin{tabular}{|c|c|c|c|c|c|c|c|c|c|}
\hline \multirow[t]{2}{*}{ S.No } & \multirow[t]{2}{*}{ Group } & \multirow[t]{2}{*}{ Dose } & \multicolumn{4}{|c|}{ Paw volume (ml) } & \multirow{2}{*}{$\begin{array}{l}\text { Difference } \\
\text { (b-a) }\end{array}$} & \multirow{2}{*}{$\begin{array}{l}\text { Men } \\
\text { value }\end{array}$} & \multirow{2}{*}{$\begin{array}{l}\text { \%anti- } \\
\text { inflammatory } \\
\text { activity } \\
(\mathrm{VcVt} / \mathrm{Vc}) \times 100\end{array}$} \\
\hline & & & $\begin{array}{l}\text { O } \\
\text { hour }\end{array}$ & $\begin{array}{l}1 \\
\text { hour }\end{array}$ & $\begin{array}{l}2 \\
\text { hour }\end{array}$ & $\begin{array}{l}3 \\
\text { hour }\end{array}$ & & & \\
\hline Group- & Control & $1 \% \mathrm{CMC}$ & 0.2 & 0.6 & 0.5 & 0.5 & 0.4 & & \multirow{6}{*}{ 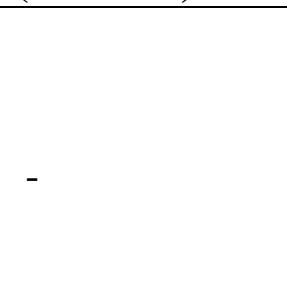 } \\
\hline \multirow[t]{5}{*}{ I } & & & 0.2 & 0.6 & 0.6 & 0.7 & 0.4 & & \\
\hline & & & 0.2 & 0.5 & 0.6 & 0.6 & 0.3 & 0.33 & \\
\hline & & & 0.2 & 0.5 & 0.6 & 0.7 & 0.3 & & \\
\hline & & & 0.2 & 0.5 & 0.5 & 0.8 & 0.3 & & \\
\hline & & & 0.2 & 0.5 & 0.7 & 0.8 & 0.3 & & \\
\hline Group- & $\mathrm{CTF}$ & $(400$ & 0.3 & 0.4 & 0.1 & 0.1 & 0.1 & & \multirow{6}{*}{$84 \%$} \\
\hline \multirow[t]{5}{*}{ II } & & $\mathrm{mg} / \mathrm{kgb} . \mathrm{wt})$ & 0.3 & 0.4 & 0.1 & 0.1 & 0.1 & & \\
\hline & & & 0.3 & 0.3 & 0.2 & 0.1 & 0 & 0.05 & \\
\hline & & & 0.3 & 0.3 & 0.1 & 0.1 & 0 & & \\
\hline & & & 0.3 & 0.4 & 0.2 & 0.1 & 0.1 & & \\
\hline & & & 0.3 & 0.3 & 0.2 & 0.1 & 0 & & \\
\hline \multirow{6}{*}{$\begin{array}{l}\text { Group- } \\
\text { III }\end{array}$} & \multirow[t]{6}{*}{ CTF } & $(200 \mathrm{mg} / \mathrm{kg}$ & 0.3 & 0.4 & 0.2 & 0.2 & 0.1 & \multirow{7}{*}{0.2} & \multirow{7}{*}{$39 \%$} \\
\hline & & b.wt) & 0.3 & 0.6 & 0.2 & 0.2 & 0.3 & & \\
\hline & & & 0.3 & 0.3 & 0.2 & 0.3 & 0 & & \\
\hline & & & 0.3 & 0.6 & 0.2 & 0.3 & 0.3 & & \\
\hline & & & 0.3 & 0.6 & 0.4 & 0.5 & 0.3 & & \\
\hline & & & 0.3 & 0.5 & 0.3 & 0.4 & 0.2 & & \\
\hline \multirow{4}{*}{$\begin{array}{l}\text { Group- } \\
\text { IV }\end{array}$} & \multirow[t]{4}{*}{ TTS } & $(200 \mathrm{mg} / \mathrm{kg}$ & 0.3 & 0.5 & 0.1 & 0.1 & 0.2 & & \\
\hline & & b.wt) & 0.3 & 0.6 & 0.4 & 0.3 & 0.3 & \multirow{3}{*}{0.18} & \multirow{3}{*}{$45 \%$} \\
\hline & & & 0.3 & 0.5 & 0.2 & 0.1 & 0.2 & & \\
\hline & & & 0.3 & 0.5 & 0.1 & 0.2 & 0.2 & & \\
\hline
\end{tabular}






Table-3 Antidiabetic activity of Clitoria ternata flower (CTF) \& Tribulus terristris seed (TTS)

\begin{tabular}{lllll}
\hline Group & Dose & Normal level & $\begin{array}{l}\text { Glucose level after } \\
\text { alloxan }\end{array}$ & $\begin{array}{l}\text { Glucose level after drug } \\
\text { treatment }\end{array}$ \\
\hline control & $0.3 \% \mathrm{cmc}$ & $93.64 \pm 4.25$ & $312.16 \pm 12.04$ & $338.10 \pm 10.12$ \\
glimenclamide & $10 \mathrm{mg} / \mathrm{kg}$ & $98.34 \pm 6.08$ & $302.05+8.56$ & $102.34 \pm 8.34^{\mathrm{a}}$ \\
CTF & $200 \mathrm{mg} / \mathrm{kg}$ & $102.12 \pm 10.12$ & $308.46 \pm 20.03$ & $198.16 \pm 15.08^{\mathrm{b}}$ \\
CTF & $400 \mathrm{mg} / \mathrm{kg}$ & $88.63 \pm 1.02$ & $304.24 \pm 5.08$ & $103.64 \pm 3.14^{\mathrm{a}}$ \\
TTS & $200 \mathrm{mg} / \mathrm{kg}$ & $112.12 \pm 10.12$ & $328.46 \pm 10.03$ & $188.16 \pm 15.08^{\mathrm{a}}$ \\
TTS & $400 \mathrm{mg} / \mathrm{kg}$ & $83.63 \pm 1.02$ & $314.24 \pm 5.08$ & $113.64 \pm 3.14 \mathrm{~b}$ \\
\hline
\end{tabular}

Values are Mean \pm SEM of Six Animals. Statistical Significance: $a=p<0.001$ and $b=p<0.05$ as compared to control.

\section{RESULTS AND DISCUSSION}

In our study the ethanoloic extracts of Clitoria ternatea flower showed potential antiinflammatory activity at a dose of $400 \mathrm{mg} / \mathrm{kg}$ level. From this study it was predicted that saponins and flavonoids after absorption from the GIT they cross the blood brain barrier (BBB) and then enter into the brain and amplify the signaling in the basal hypothalamus energy sensing function. Previous studies showed, the anti inflammatory, analgesic studies of petroleum ether extract (6080c) from the flowers of Clitoria ternatea showed that it exhibited significant anti inflammatory activity at both the dose level (200 and $400 \mathrm{mg} / \mathrm{kg}$ body weight) $(\mathrm{P}<0.01)$.(11). Clitoria ternatea roots methanol extract when given by oral route to rats was found to inhibit both the rat paw oedema caused by carrageenin and vascular permeability induced by acetic acid in rats (12) In our study the ethanoloic extracts of Clitoria ternatea flower showed potential anti-diabetic activity at a dose of $400 \mathrm{mg} / \mathrm{kg}$ level. Previous studies showed, Antihyperglycenmic Clitorea 
ternatea showed antihyperglycenmic activity (13). Flavonoids, tannins, alkaloids, saponins, tri terpinoids, glycosides are highly soluble in ethanol than the ethyl acetate and hexane $(14,15)$ Flavonoids, tannins(16), alkaloids(18), tri terpinoids (17), glycosides having potential antidiabetic activity.

In our study the ethanoloic extracts of Tribulus terristris seed showed anti-inflammatory activity at a dose of $400 \mathrm{mg} / \mathrm{kg}$ level. From the previous literature it was revealed that, T. terrestris has been used in traditional medicine for relieving rheumatic pain and as an analgesic plant for a long time. In this investigation the analgesic effect of methanolic extract of this plant on male albino mice was evaluated by formalin and tail flick test. T. terrestris extract has a suitable analgesic effect and further studies are required to produce a more effective product of this plant to substitute for conventional analgesic drugs (19). Hence the extract having some considerable anti-inflammatory activity.

In our study the ethanoloic extracts of Tribulus terristris seed showed potential anti-diabetic activity at a dose of $400 \mathrm{mg} / \mathrm{kg}$ level. This observed potential anti-hyperglycaemic activity might be due to the large presence of saponins in T. terrestris [20]. Saponin from T. terrestris reported to possess hypoglycemic properties and produced protective effect in streptozotocin-induced diabetic rats by inhibiting oxidative stress [21].

\section{SUMMARY AND CONCLUSION}

The two plants powders were procured from ayuervedic shop. Extraction was carried out using ethanol by a simple maceration technique. Wistar albino rats of either sex (150-200 g) were used for the ex vivo study. Preliminary phytochemical screening of Clitoria ternata flower \& Tribulus terristris seed extracts were done to test the presence of the active chemical constituents such as alkaloids, flavonoids, tannins, phenolic compounds, saponins, fixed oils and fats. Acute toxic studies were performed for both CTF and TTS extracts at a dose of $2000 \mathrm{mg} / \mathrm{kg}$ body weight in 2 groups of 6 rats respectively. From the acute toxicity studies the ED 50 of the extract were fixes as 200 and $400 \mathrm{mg} / \mathrm{kg}$. The anti-inflammatory and anti-diabetic activity of both CTF \& TTS were calculated by in-vivo methods using rat models. The $400 \mathrm{mg} / \mathrm{kg}$ of both Clitoria ternata flower (CTF) and Tribulus terristris seed (TTS) extracts showed potential anti-inflammatory and anti-diabetic activity. The pharmacological activity of extracts may be due to., Antiinflammatory of CTF - The presence of saponins and flavonoids. Anti-diabetic activity of CTF The presence of Flavanoids, Tannins and Terpinoids Anti-inflammatory of TTS - Previous Research work on analgesic activity. Anti-diabetic activity of TTS - Large presence of Saponins 
Further studies are required for structural elucidation of the active component(s) involved in the anti-hyperglycaemic and anti-inflammatory activity of Tribulus terrestris L. and Clitoria ternate.

\section{REFERENCES}

1. Tiwari AK, Rao JM. Diabetes mellitus and multiple therapeutic approaches of phytochemicals: present status and future prospectus. Current Sci 2002;83(1):30-8.

2. Tiwari AK. Wisdom of Ayurveda in perceiving diabetes: Enigma of therapeutic Recognition. Current Sci 2005;88(7):1043-51.

3. Wild S, Roglic G, Green A, Sicree R, King H. Global prevalence of Diabetes. Diabetes care 2004;27(5):1047-51.

4. Rang HP, Dale MM, Ritter JM, Moore PK. Pharmacology. $5^{\text {th }}$ ed. New Delhi: Elsevier:2005.p.385-7

5. Shi J, Arunasalam K, Yeung D, Kakuda Y, Mittal G. Phytate from edible beans: chemistry processing and health benefits. Food Agri Environ 2004;2(1):48-58

6. Colodny L, Hoffman RL. Inositol clinical applications for exogenous use. Altern Med Rev 1998;3(6):432-47.

7. Inositol Hexaphosphate [editorial]. Altern Med Rev 2002;7(3): 244-8

8. Lehtihet M, Honkanen RE, Sjohdm A. Inositol hexakisphosphate and sulfonyl ureas regulate $\square$-cell protein phosphatases. Biochem Biophys Res Commun 2004; 316(3): 893-7.

9. Vucenik I, Passaniti A, Vitolo MI, Tantivejkul K, Eggleton P, Shamsuddin AM. Anti angiogenic activity of inositol hexaphosphate (IP6). Carcinogenesis 2004;25(11):211523.

10. Onomi S, Okazaki Y, Katayama T. Effects of dietary level of phytic acid on hepatic and serum lipid status in rats fed a high-sucrose diet. Biosci Biotechnol Biochem 2004;66(6):1379-81.

11. Chauhan N, Rajvaidhya S and Dudey BK(2012). Pharmacognostical,phytochemical and pharmacological review on Clitoria ternatea for antiasthmatic activity. International Journal of Pharmaceutical and Sciences and Researches, 3: 398-404

12. Devi BP, Boominathan R and Mandal SC (2003). Anti-inflammatory, analgesic and antipyretic properties of Clitoria ternatearoot. Fitoterapia,74: 345- 349.

13. Patil AP and Patil VR (2011). Clitoria ternatea Linn. An Overview. International Journal of Pharmaceutical Research,3: 20-23. 
14. Khandelwal, K. R. Practical pharmacognosy (2008): Pragati Books Pvt. Ltd.

15. Khoddami, A., Wilkes, M. A., \& Roberts, T. H. Techniques for analysis of plant phenolic compounds. Molecules (2013), 18 : 2328-2375

16. Fried, B., \& Sherma, J. Practical thin-layer chromatography (1996) : a multidisciplinary approach: CRC Press.

17. Khoddami, A., Wilkes, M. A., \& Roberts, T. H. Techniques for analysis of plant phenolic compounds. Molecules (2013), $18: 2328-2375$.

18. Mali, P. Y., Bigoniya, P., Panchal, S. S., \& Muchhandi, I. S. Anti-obesity activity of chloroform-methanol extract of Premna integrifolia in mice fed with cafeteria diet. Journal of Pharmacy And Bioallied Sciences (2013) 5 : 229.

19. Heidari MR, Mehrani M, Pardakhty A (2007). The Analgesic Effect of Tribulus terrestris Extract and Comparison of Gastric Ulcerogenicity of the Extract with Indomethacine in Animal Experiments, Annals of the New York Academy of Sci., 1095: 418-42

20. Amin A, Lotfy M, Shafiullah M, Adeghate E. The protective effect of Tribulus terrestris in diabetes. Ann N Y Acad Sci. 2006; 1084: 391-401

21. Su L, Chen G, Feng SG, Wang W, Li ZF, Chen H, et al: Steroidal saponins from Tribulus terrestris . Steroids 2009; 74: 399-403. 